\title{
Determination of Some Heavy Metals in the Liver, Kidney and Tissue of Cow in Selected Abattoirs in Port Harcourt
}

\author{
Ubong, ${ }^{1}$ I. U., Obunwo, ${ }^{2} \mathrm{C} .,{ }^{2}$ Woluchem, A. \\ ${ }^{1}$ Institute of Pollution studies (IPS),Rivers State University of Science and Technology, Nkpolu Oroworukwu, \\ Port Harcourt, Rivers State. Nigeria. \\ ${ }^{2}$ Dept. of Chemistry, Faculty of Science, Rivers State University of Science and Technology, Nkpolu \\ Oroworukwu, Port-Harcourt, Nigeria.
}

\begin{abstract}
The determination of some metals in the liver, kidney and tissue of cows was carried out in selected abattoirs in Port Harcourt. Four metals were determined ( $\mathrm{Mn}, \mathrm{Ni}, \mathrm{Fe}$ and $\mathrm{Cd}$, using Flame Atomic Absorption spectrophotometer, Agilent Technologies 55A, Model 55B. Analysis was done after digestion using standard procedures. The metal results were $\mathrm{Cd}(<0.001 \mu \mathrm{g} / \mathrm{g}$ liver, $<0.001 \mu \mathrm{g} / \mathrm{g}$ Kidney, $3.20-29.60 \mu \mathrm{g} / \mathrm{g}$ in tissue with a mean of $18.08 \pm 13.15 \mu \mathrm{g} / \mathrm{g}) ; \mathrm{Mn}(8.18-9.47 \mu \mathrm{g} / \mathrm{g}$, with a mean of $8.72 \pm 0.67 \mu \mathrm{g} / \mathrm{g}$ in the liver, $5.57-6.50$ $\mu \mathrm{g} / \mathrm{g}$ with a mean of $6.5 \pm 0.47 \mu \mathrm{g} / \mathrm{g}$ in the kidney, $1.93-3.86 \mu \mathrm{g} / \mathrm{g}$ in the tissue, with a mean of $2.79 \pm 0.99$ $\mu \mathrm{g} / \mathrm{g})$. Ni $(7.93-11.70 \mu \mathrm{g} / \mathrm{g}$ with a mean of $9.62 \pm 1.92 \mu \mathrm{g} / \mathrm{g}$ in the liver, $1.70-3.30 \mu \mathrm{g} / \mathrm{g}$ with a mean $2.72 \pm$ $0.89 \mu \mathrm{g} / \mathrm{g}$ kidney, $\mathrm{Nd}<0.001 \mu \mathrm{g} / \mathrm{g}$ for tissue). Fe $(512.67-723.20 \mu \mathrm{g} / \mathrm{g}$, with a mean of $606.85 \pm 106.86 \mu \mathrm{g} / \mathrm{g}$ in the liver; $596.20-636.60 \mu \mathrm{g} / \mathrm{g}$ in the kidney, with a mean of $613.25 \pm 21.0 \mu \mathrm{g} / \mathrm{g}, 137.60-225.87 \mu \mathrm{g} / \mathrm{g}$ in the tissue, with a mean of $176.77 \pm 44.96 \mu \mathrm{g} / \mathrm{g}$ ). The result showed highest concentration in the liver followed by the kidney. Tissue had the lowest concentration of metals. The sequence of concentration was liver > kidney> tissue. This implies that people who cherish the eating of this part must consider the risk to heavy metal accumulation in their systems.
\end{abstract}

Keywords: Trace metals, Cow Tissue, Liver, Kidney, Port Harcourt.

\section{INTRODUCTION}

Meat is a rich and convenient source of nutrients such as proteins and micronutrients (Akoto et al., 2014, Akan et al., 2010). Cow meat popularly called 'beef' is one of the most widely consumed meats in the world when compared to other sources like goat, turkey, chicken, etc. Being the most widely consumed, there is every possibility of high contamination by metals due to a number of sources including: nature of grazing grounds, poor handling in abattoirs and during transportation to the end users. Trace metals are metals in extremely small quantity that are present in animals, plant cells and tissue (Murray, 2008). Trace elements are found only in minute quantities in the body. They are classified into essential, non essential and toxic groups (WHO, 1973). At low concentrations, essential trace metals play an important role in metabolism and biological process as enzyme activators (Kincaid, 1999). The heavy metal content of cow meat is poorly documented, particularly in Nigeria. However, literature sources have identified and reported food consumption as the major pathway of human exposure to pollutants, which accounts for $90 \%$ compared to other ways of exposure like inhalation and dermal contact (Akoto et al., 2014; Zheng et al., 2007; Loutfy et al., 2006).

There is a serious concern for the accumulation of heavy metals in meat because of food safety issues and potential health risks arising from the fact that heavy metals are toxic even at very low concentrations in nature (Akan et al., 2010; Santhi et al., 2008; McLaughlin et al., 1999, Mahaffey, 1977, Akoto et al., 2014). Apart from toxicity, contamination with heavy metals also results in bioaccumulation and biomagnifications in the food chain (Demirezen and Uruc, 2006).A review of related works has shown a study of heavy metal determination in cattle liver (Beyersmann, 2008, Esther et al., 2007, Puls, 1988; Abou-Arab, 2001 and Iwegbue, 2008) and another study reporting mean concentrations for some essential trace metals (Marta et al., 2005).

The risk connected with the exposure to heavy metals in food and food products has generated widespread concern about human health. The intake of these contaminants by animals e.g. cows, causes deposition of residues in meat (Akan et al., 2010). Higher levels of metals reported for beef and mutton (sheep) have been attributed to grazing on contaminated soils (Sabir et al., 2003). Gonzalez-Waller et al. (2006), also recorded the levels of toxic metals (lead and cadmium) in meat product exceeding recommended limits. Toxic effects of metals have been described in animals under relatively low levels of metal exposure (Kostial, 1986); one such effect is the disruption of trace element metabolism (Goyer, 1997; Lo'pez- Alonso et al., 2002). 
Instances of heavy metal contamination in meat products during processing have been reported (Santhi et al., 2008; Brito et al., 2005). In other cases, contaminated animal feed and rearing of livestock in proximity to polluted environment are reportedly responsible for heavy metal contamination in meat (Miranda et al., 2005; Sabir et al., 2003; Koréneková et al., 2002). It is also reported that contamination of meat can be caused by dirty slaughter places. One of the three abattoirs studied, is located in the industrial area of Port Harcourt, where there are mini-power houses, market, turbine power generation, etc. These can lead to contamination of the meat being slaughtered and handled in such abattoir.

Poor handling of meat is evident in the manner of transportation and carriage, for instance carrying the slaughtered meat openly in a wheelbarrow from the abattoirs to the open market, thereafter to end users. Traders usually make use of metal materials for meat distribution while handling the slaughtered meat (wheelbarrow, knife, basins, etc). This can equally introduce metal particulate as contaminants into the meat meant for human consumption. As a result of the foregoing, a high level of metal particulate is likely to be found in cow abattoirs situated close to any of these industries. This formed the basis of use of abattoirs for the study (Rumuokoro Abattoir, Slaughter Abattoir (Woji), Nkpolu Oroworukwo (Mile 3).

There is a high demand of liver meat in our society today. Kidney is also an important part of meat humans find as a delicacy. The tissue is the most common part of meat widely used in many homes today. This is because tissue is a great source of protein and proteins are great for providing the body with longer lasting energy which is used by the body to maintain cellular functions and it contains vitamins and minerals. Above all, it is one of the cheapest in the market so a lot of people go for it due to the low prize; hence the need to access the level of some heavy metal contents in liver, kidney and tissue in this research.

This aim of this study was to determine the levels of heavy metals ( Mn, Ni, Fe and Cd, in different organs (liver, Kidney and tissue of meat) of cow, obtained from three abattoirs in Port Harcourt, Rivers State, Nigeria.

\section{Description of the Study Area}

The study area is located in Port Harcourt metropolis. Port Harcourt is an industrialized cosmopolitan city located in the heart of the Niger Delta. The study area lies south east of the Niger Delta within Latitudes $4^{\circ} 31^{\prime}-$ $4^{\circ} 40^{\prime} \mathrm{N}$ and Longitudes $7^{0} 0^{\prime}-7^{\circ} 10^{\prime} \mathrm{E}$. It has an elevation of about $10-15 \mathrm{~m}$ above sea level.

\section{II.}

\section{MATERIALS AND METHODS}

\subsection{Sample Collection}

Fresh samples of the liver, kidneys and the tissues of beef (cow) were collected randomly immediately the cows were slaughtered in the three different abattoirs located in Port Harcourt (Trans Amadi, Rumuokoro and Mile 3 abattoirs). The samples were collected in polythene bags and sent to the laboratory for analysis. The study was conducted in the month of June, 2013 for the first set (A), and another set (B) after two months). The cows were meant for consumption as meat (beef) and so were not selected on the basis of sex or age.

\subsection{Sample Preparation}

The collected samples were dried in an oven for three days at a temperature of $105{ }^{0} \mathrm{C}$ after which they were ground and turned into fine powder. Thereafter, $2 \mathrm{~g}$ of each sample was weighed into $100 \mathrm{~cm}^{3} \mathrm{kjeldahl}$ flasks. Then $20 \mathrm{ml}$ of deionized water was added followed by $20 \mathrm{ml}$ of concentrated $\mathrm{HNO}_{3}$. The mixtures were boiled to about $100{ }^{0} \mathrm{C}$ for $1 \mathrm{hr}$ (60 minutes) to form colloidal solution, which was cooled and later, $10 \mathrm{ml}$ of concentrate $\mathrm{H}_{2} \mathrm{SO}_{4}$ was added and heated again at a temperature of $140{ }^{\circ} \mathrm{C}$ for 20 minutes, until a dense white fume of concentrated $\mathrm{H}_{2} \mathrm{SO}_{4}$ was observed. The solution was allowed to cool and thoroughly shaken and filtered into a $100 \mathrm{ml}$ standard flask. It was then made up to the mark with deionized water. $\mathrm{Cd}, \mathrm{Mn}, \mathrm{Ni}$, and $\mathrm{Fe}$, were determined using, Flame Atomic Absorption spectrophotometer (Agilent Technologies 55A Model spectra 55B). The wavelengths used were as follows: Cd, $228.8 \mathrm{~nm}, \mathrm{Fe} 248.3 \mathrm{~nm}, \mathrm{Mn} 279.5 \mathrm{~nm}$ Ni $232.0 \mathrm{~nm}$. The sample blank was prepared using the same procedure. The instrument was previously calibrated using Standard solutions of the respective metals to establish standard curves before metal analysis. Concentrations of all metals were determined by the flame method using acetylene gas as fuel.

\section{RESULTS AND DISCUSSION}

The results of heavy metal concentrations in the various parts of meat (tissue, liver and the kidney of cow) are presented in Figures 1 - 9 and Tables 1-4.

Cadmium, Cd concentrations ranged from $3.2-29.6 \mu \mathrm{g} / \mathrm{g}$, with a mean of $18.08 \pm 13.2 \mu / \mathrm{g}$ in the tissue, and $<0.001 \mu / \mathrm{g}$ in the liver and kidney (Fig.1). The highest concentration of $\mathrm{Cd}$ in the tissue was obtained in Woji 
Slaughter $(29.60 \mu \mathrm{g} / \mathrm{g})$, followed by Nkpolu-Oroworukwo (mile 3) with a value of $(21.45 \mu \mathrm{g} / \mathrm{g}$ ) while the least was at Rumuokoro abattoir $(3.20 \mu \mathrm{g} / \mathrm{g}$ ) (Table 3.1). Concentrations in other organs of cow e.g. liver and kidney were below the detection limits $(<0.001 \mu \mathrm{g} / \mathrm{g})$ and can be represented thus: Tissue $>$ liver and kidney.

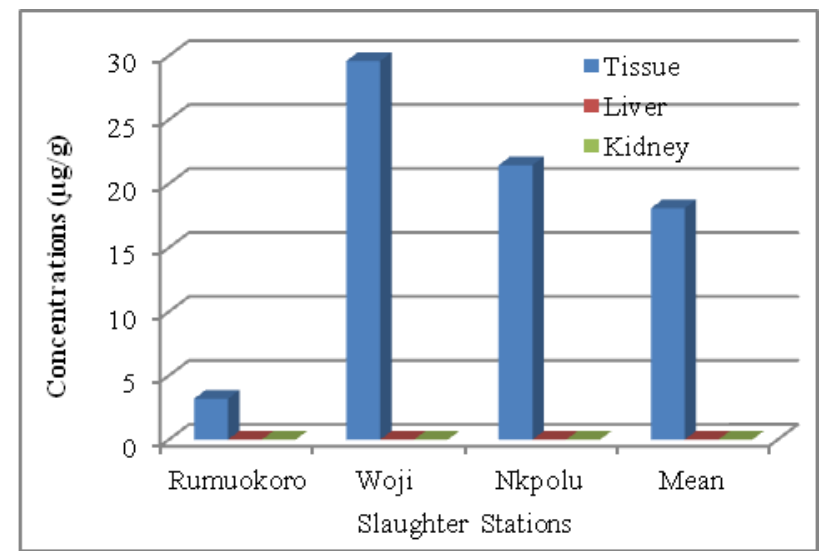

Fig.1: Cadmium distribution in meat parts in the various slaughter stations

Table 1: Cadmium concentrations in the three parts of meat studied $(\mu \mathrm{g} / \mathrm{g})$

\begin{tabular}{|l|l|l|r|r|r|}
\hline Organs & Rumuo & Woji & Nkpolu & Mean & Std. Dev. \\
\hline Tissue & 3.2 & 29.6 & 21.45 & 18.08 & 13.15 \\
\hline Liver & $<0.001$ & $<0.001$ & $<0.001$ & $<0.001$ & $<0.001$ \\
\hline Kidney & $<0.001$ & $<0.001$ & $<0.001$ & $<0.001$ & $<0.001$ \\
\hline \multicolumn{6}{c|}{ N = Rumuokoro, S = Slaughter (woji) } \\
N = Nkpolu_Oroworukwo (mile 3)
\end{tabular}

The ranges of Manganese $(\mathrm{Mn})$ concentrations in the three abattoirs were: liver $(8.18-9.47) \mu \mathrm{g} / \mathrm{g}$, with a mean of $8.72 \pm 0.67 \mu \mathrm{g} / \mathrm{g}$; kidney $(5.57-6.57 \mu \mathrm{g} / \mathrm{g})$, with a mean of $6.05 \pm 0.47 \mu \mathrm{g} / \mathrm{g}$ and Tissue $(1.93-3.86) \mu \mathrm{g} / \mathrm{g}$, with a mean of $2.76 \pm 0.99 \mu \mathrm{g} / \mathrm{g}$ (Fig. 2). The liver had the highest accumulation of all body parts, followed by the kidney. Tissue was the least in terms of Manganese content. Of the study sites, Woji slaughter had the highest concentration of manganese like cadmium, followed by Rumuokoro and Mile 3. There was no significant difference between the manganese contents in the tissue and liver $(p<0.05)$; kidney and the liver $(p<0.05)$ when compared. The concentration of manganese, like nickel, in the three abattoirs increased in the order of liver $>$ Kidney $>$ tissue (Table 2).

Table 2: Manganese concentrations in the three parts of meat studied $(\mu \mathrm{g} / \mathrm{g})$

\begin{tabular}{|c|l|l|l|l|l|}
\hline Organs & Rumuokoro & Woji & Nkpolu & Mean & $\begin{array}{c}\text { Std. } \\
\text { Dev. }\end{array}$ \\
\hline Tissue & 2.5 & 3.86 & 1.93 & 2.76 & 0.99 \\
\hline Liver & 8.5 & 9.47 & 8.18 & 8.72 & 0.67 \\
\hline Kidney & 6.08 & 5.57 & 6.5 & 6.05 & 0.47 \\
\hline
\end{tabular}




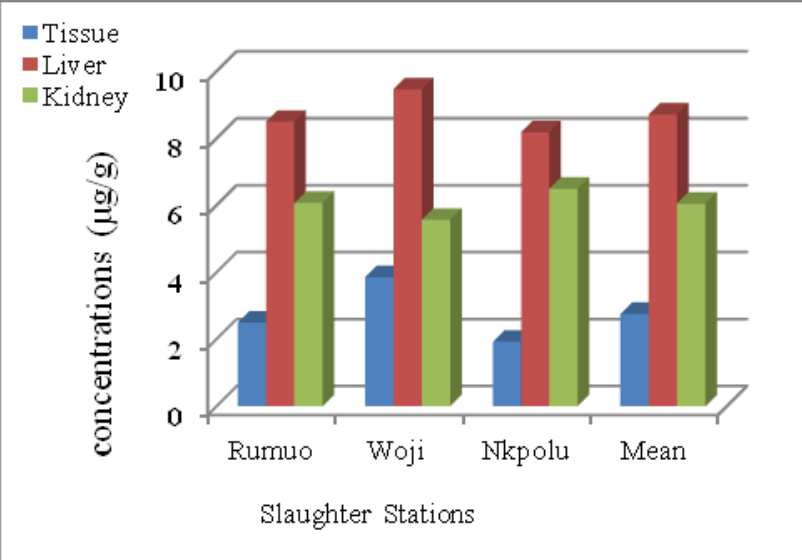

Fig. 2: Manganese concentrations in meat parts in the three abattoirs studied

Nickel

The ranges of Ni concentrations in the cow meat were: liver $(7.93-11.70) \mu \mathrm{g} / \mathrm{g}$, kidney $(1.70-3.30) \mu \mathrm{g} / \mathrm{g}$ and tissue $(<0.001) \mu \mathrm{g} / \mathrm{g}$ (Fig. 3; Table 3). The organ with the highest concentration was the liver followed by the kidney. The slaughter with the highest concentration of Nickel was Rumuokoro followed by Woji and Nkpolu (Fig. 3). There was a significant difference between the nickel contents in the kidney and the liver $(p>0.05)$. The concentration of Nickel in the three abattoirs increased in the order of liver $>$ Kidney $>$ tissue (Table 3).

Table 3: Nickel concentrations in the three parts of meat studied $(\mu \mathrm{g} / \mathrm{g})$

\begin{tabular}{|l|l|r|r|r|r|}
\hline Organs & Rumuo & \multicolumn{1}{l|}{ Woji } & Nkpolu & Mean & $\begin{array}{l}\text { Std. } \\
\text { Dev. }\end{array}$ \\
\hline Tissue & $<0.001$ & $<0.001$ & $<0.001$ & $<0.001$ & 0.00 \\
\hline Liver & 11.7 & 9.22 & 7.93 & 9.62 & 1.92 \\
\hline Kidney & 3.18 & 3.3 & 1.7 & 2.73 & 0.89 \\
\hline
\end{tabular}

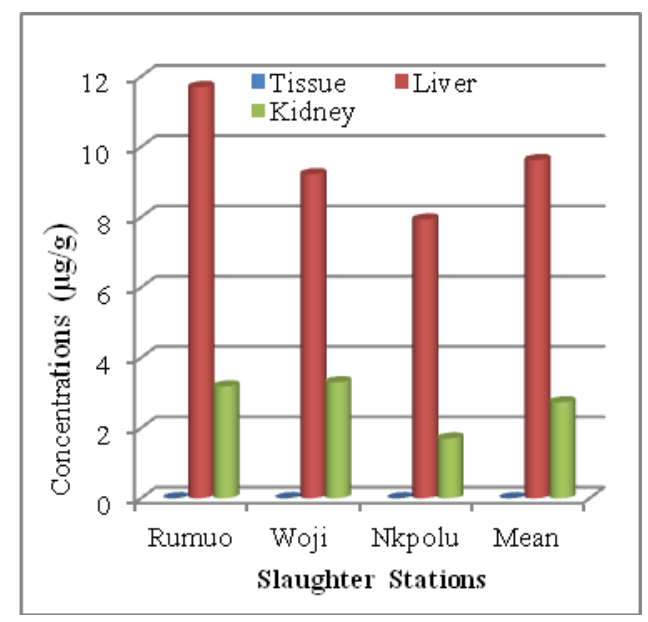

Fig. 3: Nickel concentrations in meat parts in the three abattoirs studied

Table 4: Iron concentrations in the three parts of meat studied $(\mu \mathrm{g} / \mathrm{g})$ 


\begin{tabular}{|l|c|l|l|l|c|}
\hline Organs & Rumuokoro & Woji & Nkpolu & Mean & $\begin{array}{c}\text { Std. } \\
\text { Dev. }\end{array}$ \\
\hline Tissue & 166.85 & 225.87 & 137.6 & 176.77 & 44.96 \\
\hline Liver & 723.2 & 584.7 & 512.67 & 606.86 & 106.86 \\
\hline Kidney & 596.2 & 636.6 & 606.97 & 613.26 & 21.00 \\
\hline
\end{tabular}

$\mathrm{R}=$ Rumuokoro, $\mathrm{S}=$ Slaughter (Woji); $\mathrm{N}=$ Nkpolu_Oroworukwo (Mile 3)

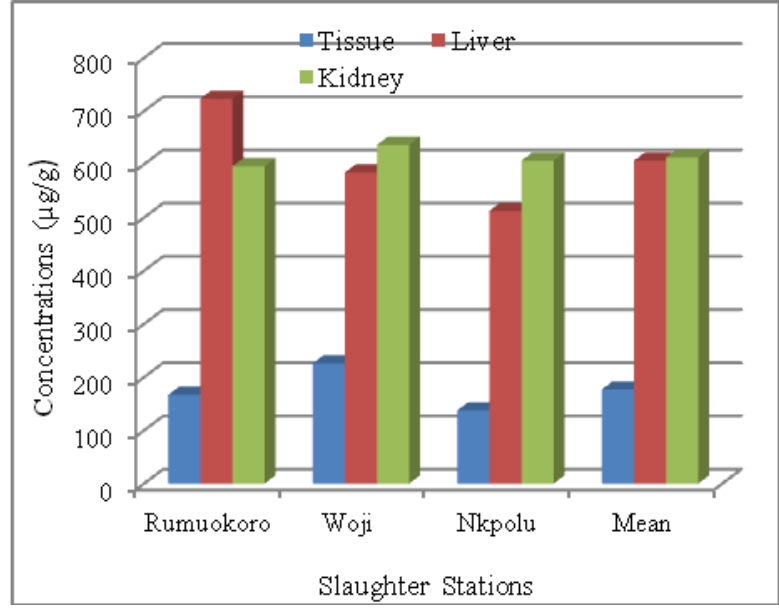

Iron

Fig. 4: Iron concentrations in meat parts in the three abattoirs studied

The ranges of iron concentrations in the meat were: liver $(512.67-723.20) \mu \mathrm{g} / \mathrm{g}$, with a mean of $606.85 \pm 106.9$ $\mu \mathrm{g} / \mathrm{g}$; kidney $(596.20-636.60) \mu \mathrm{g} / \mathrm{g}$, with a mean of $613.26 \pm 21.0 \mu \mathrm{g} / \mathrm{g}$ and tissue $(137.60-225.87) \mu \mathrm{g} / \mathrm{g}$, with a mean of $176.77 \pm 45.0 \mu \mathrm{g} / \mathrm{g}$ ). The organ with the highest concentration was the liver followed by the kidney, while the tissue had the lowest concentration (Figs. 4). The slaughter with the highest concentration of Iron was Rumuokoro followed by Woji and Nkpolu. There was no statistical difference between the iron contents in the tissue and liver $(p<0.05)$ and kidney and liver $(p<0.05)$. However, concentrations can be expressed as liver $>$ kidney> tissue.

Table 5: Summary of all metal concentrations $(\mu \mathrm{g} / \mathrm{g})$ in organs of cow in all Abattoirs studied in Port Harcourt.

\begin{tabular}{|l|l|l|l|l|l|l|}
\hline & \multicolumn{2}{|c|}{ Liver } & \multicolumn{2}{c|}{ Kidney } & \multicolumn{2}{c|}{ Tissue } \\
\hline Metal & Range & Mean+Std. & Range & Mean+Std. & Range & Mean+Std. \\
\hline $\mathrm{Cd}$ & $<0.001$ & $<0.001$ & $<0.001$ & $<0.001$ & $3.2-29.6$ & $18.08 \pm 13.2$ \\
\hline $\mathrm{Mn}$ & $8.2-9.5$ & $8.72 \pm 0.7$ & $5.6-$ & $6.05 \pm 0.47$ & $1.93-3.9$ & $2.79 \pm 1.0$ \\
& & & 6.5 & & & \\
\hline $\mathrm{Ni}$ & $7.9-11.7$ & $9.62 \pm 1.9$ & $1.7-$ & $2.72 \pm 0.9$ & $\mathrm{ND}$ & $<0.001$ \\
& & & 3.3 & & & \\
\hline $\mathrm{Fe}$ & $512.7-$ & $606.9 \pm 106.9$ & 596.2 & $613.3 \pm 21$ & $137.6-$ & $176.8 \pm 45.0$ \\
& 723.2 & & - & & 225.9 & \\
& & & 636.6 & & & \\
\hline
\end{tabular}

$\mathrm{ND}=<0.001$; In liver: $\mathrm{Fe}>\mathrm{Ni}>\mathrm{Mn}>\mathrm{Cd}$; In Kidney: $\mathrm{Fe}>\mathrm{Mn}>\mathrm{Ni}>\mathrm{Cd}$; In Tissue: $\mathrm{Fe}>\mathrm{Cd}>\mathrm{Mn}>\mathrm{Ni}$.

Of all metals studied, Iron was the metal with highest concentration in all organs and in all abattoirs studied when compared (Figs. $5 \& 6$ and Table 3.5). Apart from iron, nickel was the next metal in abundance (Figs. $7 \&$ 8 ) in the liver while cadmium was the least metal detected only in the tissue (Figs. $9 \& 10$ ). 


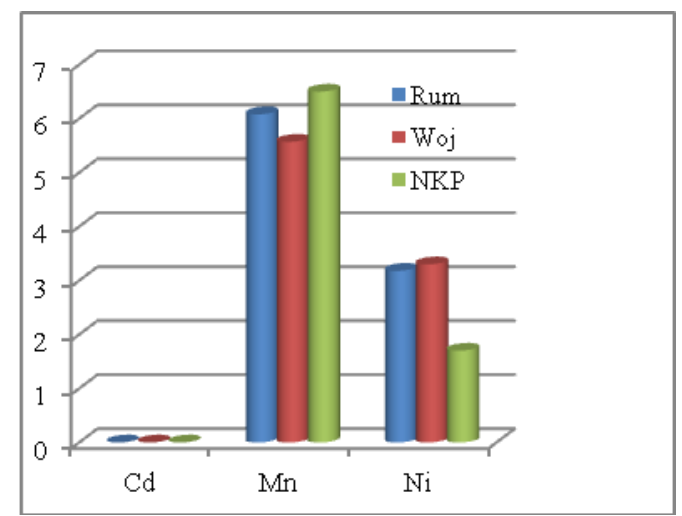

Fig. 5: Metal concentrations in the kidney part of cow in the three abattoirs studied

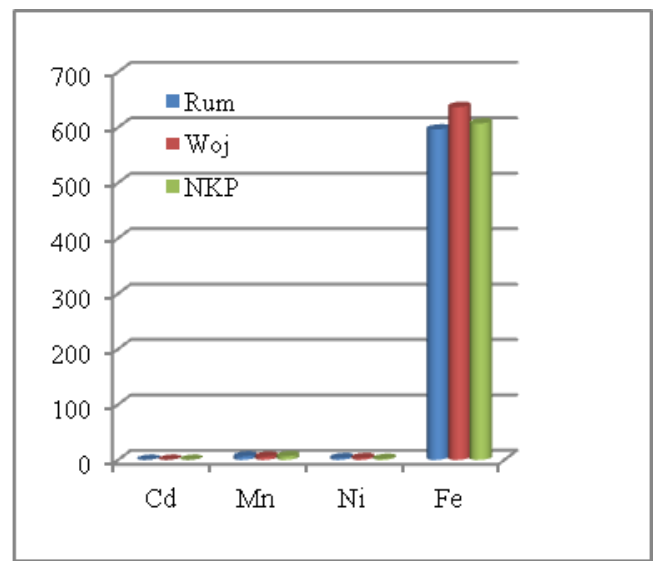

Fig. 6: Iron and other metal concentrations in the kidney part of cow in the three abattoirs studied

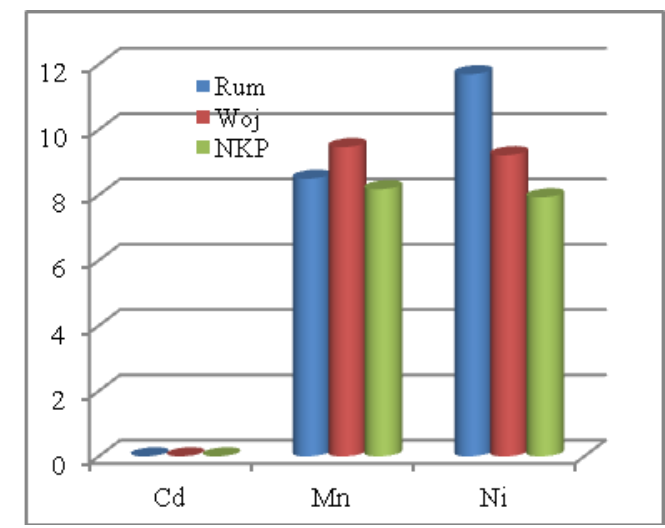

Fig. 7: Some metal concentrations in the liver part of cow in the three abattoirs studied 


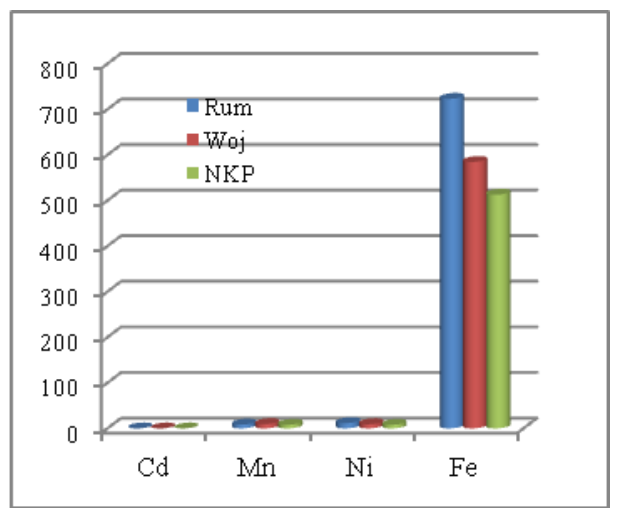

Fig. 8: Iron and other metal concentrations in the tissue part of cow in the three abattoirs studied

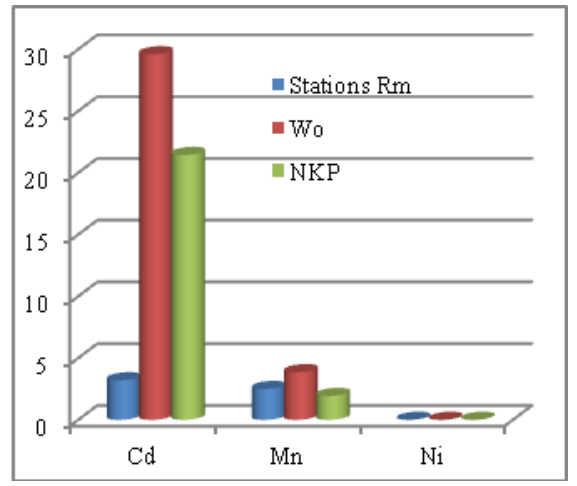

Fig. 9: Some metal concentrations in the tissue part of cow in the three abattoirs studied

\section{DISCUSSION}

Cadmium was only detected in the tissue while the concentrations in the liver and kidney were less than $(<0.001) \mu \mathrm{g} / \mathrm{g}$. The none detection in the liver and kidney may be due to the excretory properties of these organs. Cadmium concentration in the tissue varied from slaughter to slaughter but the highest was obtained in Woji slaughter followed by Nkpolu. This may imply that sources of cadmium vary from slaughter to slaughter. Differences in concentrations were not significant $(\mathrm{p}<0.05)$ for the abattoir at Woji and Nkpolu but significant for Mile three and Woji ( $>>0.05$ ). This may suggest that the sources of cadmium around Woji slaughter are more than elsewhere. Cadmium is reported to be toxic to virtually every system in the animal body (Akan et al., 2010). It is almost absent in the human body at birth, but accumulates with age. Cadmium accumulation in the kidney and liver over long time has been reported by McLaughlin et al. (1999), that cadmium interacts with a number of minerals mainly $\mathrm{Zn}, \mathrm{Fe}, \mathrm{Cu}$ and $\mathrm{Se}$ due to chemical similarities and competition for binding stage. It is also reported that $\mathrm{Cd}$ can affect $\mathrm{Ca}, \mathrm{P}$ and bone metabolism in both industrial and people exposed to $\mathrm{Cd}$ in general environment (Jarup et al., 1998). Aranha et al. (1994), and R og a-Franc et al. (1996), detected cadmium levels in the livers and kidneys of cattle in Poland and found cadmium concentration to be above the $0.5 \mathrm{ppm}$ permissible limit set by (FAO/W HO, 2000). Similarly, Doganoc (1996) found higher levels of cadmium and zinc in the livers and kidneys of the hens and chickens, which exceeded the official tolerance levels. In this study, the concentration of cadmium in all three abattoirs were obtained only in the tissues (3.2- 29.6) $\mu \mathrm{g} / \mathrm{g}$, with a mean of $18.1 \pm 13.2 \mu \mathrm{g} / \mathrm{g}$. These were much higher than the $0.5 \mathrm{ppm}$ permissible limit set by (FAO/WHO, 2000). Cadmium and Nickel are among some of the metals classified in Group 1 of the International Agency for Research on Cancer categories of carcinogen (IARC, 1993).Toxic effects of cadmium are kidney dysfunction, hypertension, hepatic injury and lung damage (John and Jeanne, 1994). The tissue recorded very high level of Cd, irrespective of the abattoirs. This trend is at variance with trends in earlier reported cases in which $\mathrm{Cd}$ concentrations were recorded in kidney and livers of cows (Falandysz and Mezera, 1994). This is due to the detoxification function of the organs where the metals are accumulated (Aranha, 1994). The trend in this study could be as a result of free grazing, drinking of water from ditches, streams, rivers and other possible contaminated water sources. Majority of cows in Port Harcourt 
graze along runways and other sites that might have been contaminated with toxic substances including industrial discharges. The permissible limits for cadmium in kidney and liver have been reported as $1 \mathrm{ppm}$ and $0.5 \mathrm{ppm}$ Cd respectively.

\section{Manganese}

The high accumulation in the liver may be due to their special functions; liver as storage and metabolic organ and kidney as an excretory organ (Stoyke et al., 1995). Manganese occurs in food in many chemical forms and combinations, which affects its availability to the animal. It is known at low concentrations for both human and animals but toxic at high levels. Manganese is an essential metal and is required for normal metabolic activity in animal. Mn is needed for growth and good health in humans, otherwise deficiency of Mn can cause nervous system problems (Demirezen and Uruç, 2006). The liver and kidney recorded high concentrations of Manganese in the order liver > kidney > tissue. The levels of Manganese reported in this study corroborate with levels reported for livers and kidney of cow from elsewhere (Iwegbue, 2008). There was no difference between Mn content in the tissue and liver meat samples ( $\mathrm{p}<0.05)$. Because manganese plays a lot of role in a variety of enzyme systems, dietary deficiency of manganese causes impaired growth, skeletal abnormalities and defects in carbohydrate and fat metabolism (Holleman et al., 1985). Manganese contents between the liver and kidney did not show any statistical difference $(\mathrm{p}<0.05)$. The highest concentration in the liver came from Woji and could suggest pollution.

\section{Nickel}

Nickel was not detected in the tissue samples analyzed. However, the concentrations in the liver samples $(9.62 \pm 1.9) \mu \mathrm{g} / \mathrm{g}$ were higher than those of the kidney $(2.73 \pm 0.9) \mu \mathrm{g} / \mathrm{g}$. The differences between nickel contents in the kidney and the liver were significant. Korenkova, et al. (2002), reported mean concentrations of 0.176-$0.231 \mu \mathrm{g} / \mathrm{g}$ in the liver of cattle reared in the vicinity of the metallurgic industry in Slovakia which is comparably lower than the mean concentrations recorded in this study. It could be inferred that the target organs for Nickel are the liver and kidney. The permissible limit for Ni in food according to WHO and USSR Standard is $0.5 \mu \mathrm{g} / \mathrm{g}$.

\section{Iron}

The concentrations of iron (Fe) in the liver and kidney of cow showed significant variations $(\mathrm{p}<0.05)$. The order in the three organs is kidney>liver $>$ tissue and the abattoir: Rumuokoro $>$ Woji $>$ Nkpolu. The high Fe levels in the organs of cow, are attributed to the fact that Iron is a major constituent of blood and since blood flows in these organs, its level, expectedly will be higher (Nielsen, 2003; NAP, 2001). Iron is an essential metal and is required for normal metabolic activity in animal. This trace element is a component of molecules that transport oxygen in blood. Numerous enzymatic reactions involving oxidation and reduction (redox) use iron as the agent through which oxygen is added, hydrogen is removed, or electrons are transferred (Nielsen, 2002; Nielsen, 2003; NAP, 2001). Excess iron in the body is stored as ferritin and hemosiderin in the liver, reticuloendothelial cells, and bone marrow (WHO, 1996). Meat is the best source of iron, but iron-fortified foods (cereals and wheat-flour products) also are significant sources of iron (NAS, 1998; W HO, 1996).

The level of Iron observed in the liver, kidney and tissue of the samples in this study are comparatively higher than mean levels of 125.2-146 $\mu \mathrm{g} / \mathrm{g}$ reported for liver, kidney and tissue of cattle from 3 regions of Slovakia (Korenkova, et al., 2002). Heavy metals could also come as a result of poor sanitation of grazing ground.

Looking at the different stations, cows purchased from Woji abattoir had the highest accumulation of trace metals followed by Rumuokoro and Nkpolu Oroworukwo (Mile 3). It is very clear from the results obtained; that the liver tends to be the highest place for the accumulation of $\mathrm{Ni}$ and $\mathrm{Mn}$, except in few exceptions that the concentrations of these metals are higher in kidney (e.g. iron) and tissue (cadmium). This is in agreement with previous findings.

In summary the liver tends to be the preferred place for accumulation by heavy metals followed by the kidney, while the tissue is the least organ for accumulation. It has been reported that livers and kidney are target organs for monitoring metal contamination in animals because both organs function in storing and removing toxic metals from the body and therefore end up in accumulating them (Abou-Arab, 2001; Husain et al., 1996; Akoto et al. 2014). High level of metals in cow has been attributed to the fact that grazing of cattle is done on contaminated soils more often than not; and that higher levels of metals have been found in beef and mutton (sheep) (Sabir et al., 2003). Gonzalez-Waller et al. (2006), also recorded the levels of toxic metals (lead and cadmium) in meat product exceeding recommended limits (Akan et al., 2010). 
In other cases, contaminated animal feed and rearing of livestock in proximity to polluted environment are reportedly responsible for heavy metal contamination in meat (Miranda et al., 2005; Sabir et al., 2003; Koréneková et al., 2002). Contamination is transferred to animals through direct sewage water and industrial effluent. Contamination of meat is reportedly caused by vehicle emission and from dirty slaughter places (Akan et al., 2010). From the findings, lovers of liver and kidney are enriching themselves with accumulation of heavy metals. This implies that responsible people should go for tissue meat instead of liver or kidney.

\section{CONCLUSION}

The liver tends to be the preferred place for accumulation of heavy metals followed by the kidney, while the tissue has the least accumulation. From the findings of this study, responsible people should go for tissue parts instead of liver and kidney. For people who must eat the liver and kidney of cow, they must consider the risk to trace metal build up in their bodies. There is also a need for continuous monitoring of these and other metals in cow in the interest of humans who consume them.

\section{ACKNOWLEDGEMENT}

The authors are grateful to the Department of chemistry, Rivers state University of Science and Technology, Port Harcourt, Nigeria, for providing the platform that led to this study.

\section{REFERENCES}

[1] Abou-Arab, A. A. K. (2001). Heavy metal contents in Egyptian meat and the role of detergent washing on their levels. Food Chem Toxicol; 39, pp. 593-599.

[2] Akan, J.C., Abdulrahman, F.I., Sodipo, O.A., Chiroma. Y.A. (2010). Distribution of Heavy Metals in the Liver, Kidney and Meat of Beef, Mutton, Caprine and Chicken from Kasuwan Shanu Market in Maiduguri Metropolis, Borno State, Nigeria. Res J App Sci, Engin and Tech; 2(8), pp. 743-748.

[3] Akoto, O, Bortey-Sam, N., Nakayama, S.M.M., Ikenaka, Y., Baidoo, E., Yohannes, Y.B., Mizukawa, H, Ishizuka, M. (2014). Distribution of Heavy Metals in Organs of Sheep and Goat Reared in Obuasi: A Gold Mining Town in Ghana. Int. J. Environ. Sci. Toxic. Res. Vol. 2(2):81-89. Available online http://www.internationalinventjournals.org/journals/IJESTR

[4] Aranha, K. (1994). Environmental Chemistry. 3rd Edn., New Age International Ltd. Publisher, New Delhi, pp: 213-219.

[5] Aranha, Kumar de, (1994). Environmental Chemistry $3^{\text {rd }}$ ed. P. 213. New Age International limited publisher, New Delhi.

[6] Brito, G., Díaz, C., Galindo, L., Hardisson, A. Santiago, D. and García, M. F. (2005). Levels of metals in canned meat products: Intermetallic correlations. Bull. Environ. Contam. Toxicol., 44(2): 309- 316.

[7] Beyersmann, D. and Hartwig. A. (2008). "Carcinogenic metal compounds: recent insight into molecular and cellular mechanisms," Archives of Toxicology, vol. 82, no. 8, pp. 493-512. View at Publisher. View at Google Scholar · View at Scopus.

[8] Demirezen, D. and K. Uruç, (2006). Comparative study of trace elements in certain fish, meat and meat products. Meat. Sci., 74: 255-260.

[9] Doganoc, D.Z. (1996). Distribution of lead, cadmium, and zinc in tissues of hens and chickens from Slovenia. Bull. Environ. Contam. Toxicol., 57: 932-937.

[10] Esther, H.Z. Martin, G; Isabel, H.P. and Alfred B (2007). Trace Mineral status of liver and blood parameters in sheep without mineral supply compared to local deer (Capreolus Capreolus) populations J. Chemistry and Biology (75) 2 - 3 185-191.

[11] FAO/W HO. (2000). Report of the 32nd Session of the Codex Committee of the Food Additives Contaminants. Beijing. People's Republic of China, 20-24 March.

[12] Gonzalez-W aller, D. L., Karlsson, A., Caballero, F., Hernandez, A., Gutierrez, T., GonzalezIgalesias, M. Marino and A. Hardission. (2006). Lead and cadmium in meat and meat products consumed by the population in Tenerife Islands, Spain. Food Addit. Contamin., 23: 757-763.

[13] Goyer, R. A. (1997). Toxic and essential metal interactions. Annu. Rev. Nutr., 17: 37- 50.

[14] Holleman, A. F., Wiberg, E., Wiberg, N. (1985). Luchrbuch der Anorganischem cheme (91-100ed) de Gruyter berlin.

[15] International Agency for Research on Cancer, Monographs on the Evaluation of Carcinogenic Risks on Humans, Vol. 58, 1993. 
[16] John, H. H. and Jeanne, I. R. (1994). Food Additives, Contaminants and Natural Toxins. In: Maurice, E. S., James, A.O., Moshe, S. L. and Febiger, (Eds.): Modern Nutrition in Health and Disease. 8th Edn., Part II, pp:1597-1598.

[17] Kincaid, R. L. (1999). Assessment of trace mineral status of ruminants. A review of proceedings of the American Society of Animal Science.

[18] Koréneková, B., Skalická, M. and Nad, P. (2002). Concentration of some heavy metals in cattle reared in the vicinity of metallurgic industry. Veterinarski Arhiv., 72(5): 259-267.

[19] Korenkova, B. M. Skalicka, Koncentracija, Nekih teskili. (2002). Metal Vet. arhiu 72, 259 - 267.

[20] Kostial, K. (1986). Trace Elements in Human and Animal Nutrition. 5th Edn., Hertz, W. (Ed.), Academic Press, Orlando, 2: 319-345.

[21] Lopez-Alonso, M., Benedito, J. L., Miranda, M., Castillo, C., Hernandez, J., Shore, R.F. (2002). Cattle as biomonitors of soil arsenic, copper and zinc concentrations in Galicia (NW Spain). Arch Environ Contam Toxicol; 43, pp. 103-108.

[22] Loutfy, N., Fuerhacker, M., Tundo, P., Raccanelli, S., El Dien, A.G., Ahmed, M. T. (2006.). Dietary intake of dioxins and dioxin-like PCBs, due to the consumption of dairy products, fish/seafood and meat from Ismailia city, Egypt. Sci. Total Environ: 370, pp. 1-8.

[23] Mahaffey, K.R., (1977). Mineral concentrations in animal tissues: Certain aspects of FDA regulatory role. J. Anim. Sci., 44: 509-515.

[24] Marta, M., Marta, L. A. and Jose, L. B. (2005). Copper, Zinc, Iron and manganese accumulation in cattle from Asturia (North Spain). Biological trace element (109): 134 - 135.

[25] Iwegbue, M., (2008). Heavy Metal Composition of Liver and Kidney of cattle from Southern Nigeria. Pages 401-406.

[26] McLaughlin, M. J., Parker, D. R., Clarke, J. M. (1999). Metals and micronutrients, food safety issues. Field Crops Res; 60, pp. 143-63. Merian, E. (Ed.), (1991). Metals and their Compounds in the Environment. Occurrence, Analysis and Biological Relevance. VCH, Weinheim.

[26] Miranda, M., López-Alonso, M. Castillo, C., Hernández, J. and Benedito, J. L. (2005). Effects of moderate pollution on toxic and trace metal levels in calves from a polluted area of Northern Spain. Environ. Int., 31: 543-548.

[27] Murray, M. R. P. (2008). “A place in the sun, the politics of place, identity and branding, Place Branding and Public Diplomacy 4(2): 124-135.

[28] National Academy Press, (2001). Food and Nutrition Board, Institute of Medicine, Dietary Reference Intakes for Vitamin A, Vitamin K, Arsenic, Boron, Chromium, Copper, Iodine, Iron, Manganese, Molybdenum, Nickel, Silicon, Vanadium, and Zinc. Washington, D.C.

[29] Nielsen, F. H. (2002). "Trace Mineral Deficiencies." In Handbook of Nutrition and Food, edited by Carolyn D. Berdanier, pp. 1463-1487. Boca Raton, Fla.: CRC Press.

[30] Nielsen, F. H. "Trace Elements." Encyclopedia of Food and Culture. (2003). Encyclopedia.com. 11 Apr. 2016 <http://www.encyclopedia.com>.

Puls, R. (1988). Mineral levels III. Animal Health Sherps International C Clear Book B.C. Canada.

[31] Roga-Franc, M., Kosla, T. and Rokicki, E. (1996). Cadmium concentration in organs of dairy cows depending on that element contents in meadow cover. Mengen-Spurenelem., Arbeistag., pp: 393-397.

[32] Sabir, S.M., Khan, S.W. and Hayat, I. ( 2003). Effect of environmental pollution on quality of meat in district Bagh, Azad Kashmir. Pak. J. Nutr., 2(2): 98-101.

[33] Santhi, D., Balakrishnan, V., Kalaikannan, A. and Radhakrishnan, K.T. (2008). Presence of heavy metals in pork products in Chennai (India). Am. J. Food Technol., 3(3): 192-199.

[34] Stoyke, M., Doberschutz, K. D., Lusky, K. (1995). Heavy metal contents (cadmium, lead and mercury) in selected feedstuff, organs and tissue in cattle found in different sites of Brandenburg. Mengen Spureneler Arb; 15, pp. 269-276.

[35] WHO. (1973). World Health Organization. Trace Elements in Human Nutrition. Report of World Health Organization, Technical Reports Series No. 523.

[36] World Health Organization. Trace Elements in Human Nutrition and Health. Geneva: World Health Organization, 1996.

[37] Zheng, N., Wang, Q., Zhang, X., Zheng, D., Zhang, Z., Zhang, S. (2007). Population health risk due to dietary intake of heavy metals in the industrial area of Huludao city, China. Sci Total Environ; 387, pp. 96- 104. 